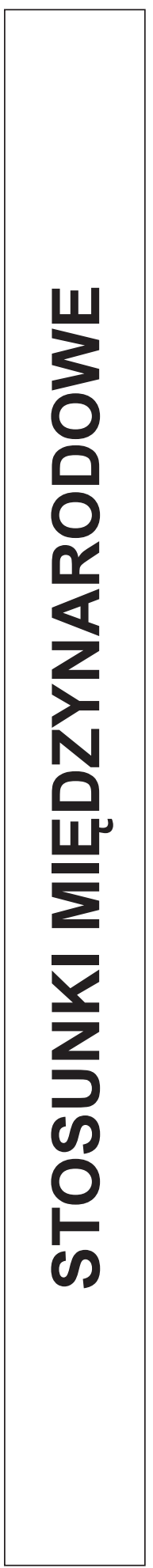





\section{WYKORZYSTANIE GIER DECYZYJNYCH/SYMULACYJNYCH W NAUKACH SPOLECZNYCH. WYBRANE PROBLEMY}

Treścią publikacji jest przedstawienie wybranych problemów prognozowania w naukach społecznych. W artykule skoncentrowano się na metodzie gier decyzyjnych - symulacyjnych, które (zwłaszcza wraz z rozwojem teorii gier oraz komputerów) są coraz częściej wykorzystywane w wielu dziedzinach. Na wybranych przykładach gier decyzyjnych/symulacyjnych - Poznań International Model United Nations 2013/POZiMUN; S.E.N.S.E. a także gry sieciowej EVE Online-wskażemy jak ważne są takie ćwiczenia, by móc precyzyjniej przewidywać przyszłość. Szczególna uwaga zwrócona zostanie na kwestię przypadku oraz czynników zakłócających, które mogą destabilizować proces przewidywania. Poruszony zostanie ponadto problem podejmowania decyzji w aspekcie klasycznej oraz kwantowej logiki - co może być pomocne przy rozpatrywaniu sytuacji mających charakter „dylematu więźnia”.

$* * *$

Prognozowanie rozumiane jest jako przewidywanie oparte na określonych, budzących zaufanie danych. Z kolei prognostyka, to nauka o przewidywaniu przyszłości. Celem naukowego prognozowania jest możliwość ukazania wizji (modelu) przyszłości w najbardziej prawdopodobnym przebiegu badanego zjawiska z uwzględnieniem kierunków oraz dynamiki jego rozwoju. W toku prognozowania dążymy także do określenia warunków, w których ewolucja analizowanego zjawiska będzie możliwa. Sporządzając w tym celu prognozę uwzględnić należy poznane zależności, rodzaje i intensywność wpływów zewnętrznych i spodziewane zmiany wewnętrzne w toku rozwoju zjawiska, będącego przedmiotem badań. Stąd też każda prognoza (rozumiana jako: sąd sformułowany zgodnie z naukowymi zasadami procesu badawczego; odnoszący się nie do przyszłości w ogóle, ale ściśle określonej; weryfikowany doświadczalnie; choć niepewny, to jednak akceptowany, czyli godny zaufania, prawdopodobny i wiarygodny) musi być dostatecznie elastyczna, wariantowa i otwarta na dynamikę wszelkich zmian istotnych dla przebiegu zjawiska (Stryjski, 2003: 1; Stryjski, 2004: 29; Guzik, Appenzeller, Jurek, 2004: 7; Donaj, 2013: 34-42).

Z prognozowaniem powiązany jest termin ,symulacje”. Słowo to pochodzi z łacińskiego „symulatio”, co najczęściej tłumaczy się jako udawanie lub - co gorsza - fałszywe prezentowanie rzeczywistego stanu np. zdrowia (powszechnie znane jest symulowanie, czyli udawanie choroby). W prognostyce nie chodzi jednak o udawanie czegokol- 
wiek, a raczej o sztuczne (wirtualne - mogące zaistnieć) antycypowanie przyszłości (Stryjski, 2004: 88).

Symulacją nazwiemy zatem niepewny sąd warunkowy o kształtowaniu się zjawiska (odpowiedź na pytanie: co by było, gdyby było) - determinanta czasowa może tu wystąpić, choć nie musi (Guzik, Appenzeller, Jurek, 2004: 8). W procesie symulacji potrzebujemy systemu i modelu (Sułek, 2010: 195; Berlinger). System jest to zbiór powiązanych ze sobą obiektów scharakteryzowanych za pomocą atrybutów (cech), które również mogą być ze sobą powiązane. Model jest uproszczoną reprezentacją systemu, w czasie i przestrzeni, stworzoną w zamiarze zrozumienia zachowania systemu rzeczywistego. Modele, które reprezentują system za pomocą logicznych i kwantyfikatorowych relacji nazywamy modelami matematycznymi. Relacjami tymi manipuluje się w ten sposób, aby określić jak model reaguje na zmiany, a więc jak zachowałby się istniejący system, pod warunkiem, że model matematyczny jest odpowiednio zaprojektowany. Jeśli zbudowany model jest prosty, istnieje możliwość zbadania działania systemu przy pomocy metod matematycznych i otrzymania w ten sposób rozwiązania analitycznego. Jednakże, większość systemów ma tak wysoki stopień złożoności, że ich matematyczne modele wykluczają możliwość analitycznego rozwiązania. W takich przypadkach (patrz rys. 1 i 2) badany model musi być analizowany przy użyciu metod symulacyjnych (Wieleba).

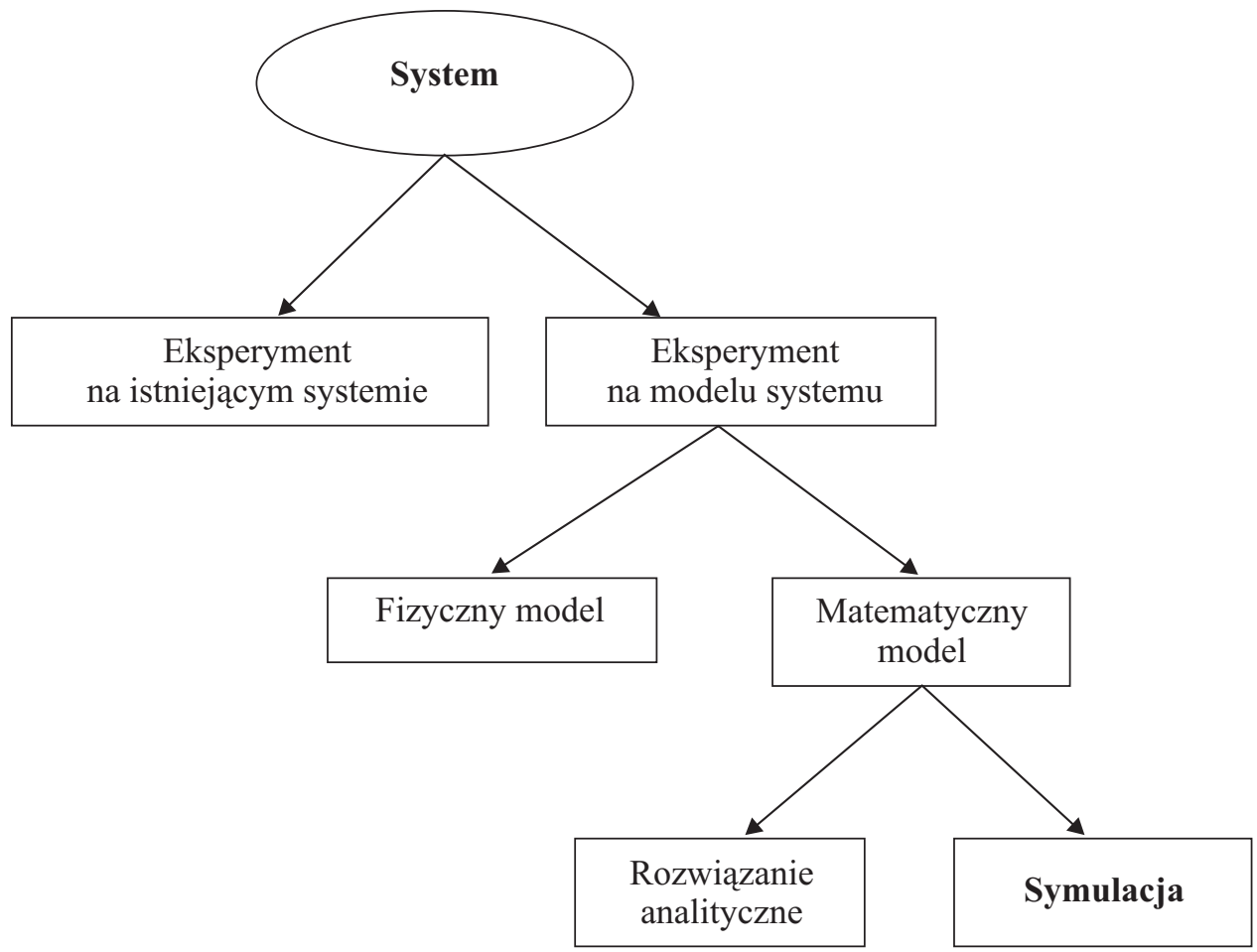

Rys. 1. Metody analizy systemu

Źródło: R. Wieleba, Symulacja, http://csikgw.aon.edu.pl/index.php/pl/symulacja/87-symulacja.html (31.07.2013). 


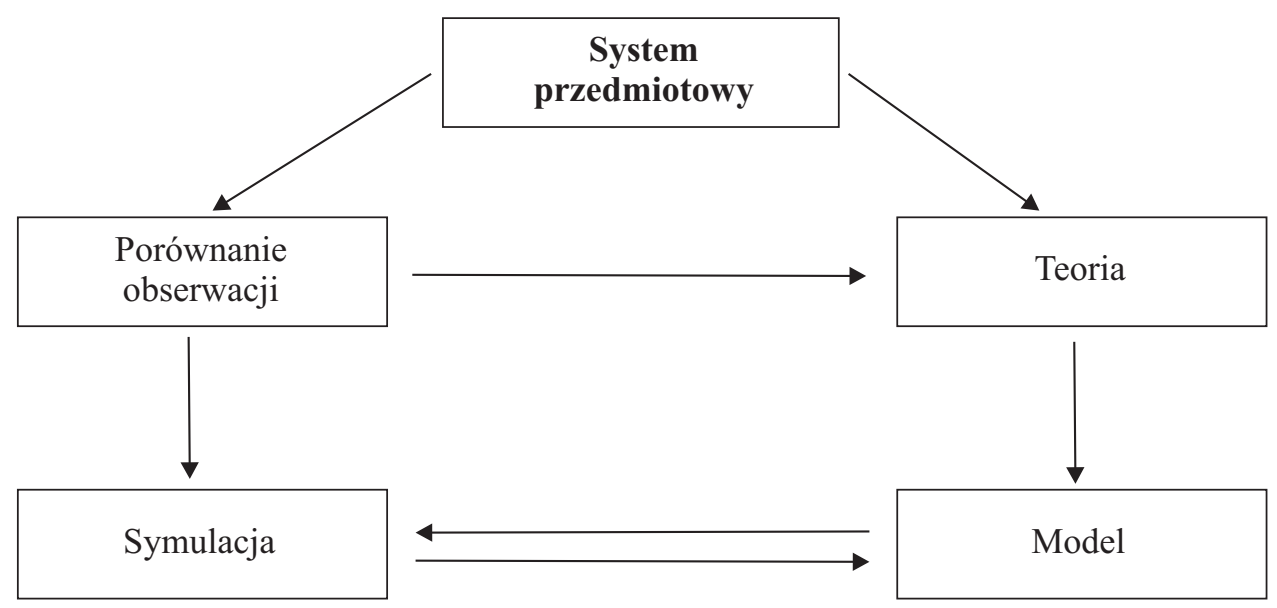

Rys. 2. System przedmiotowy, model, symulacja

Źródlo: R. Wieleba, Symulacja, http://csikgw.aon.edu.pl/index.php/pl/symulacja/87-symulacja.html (31.07.2013).

Symulacja to manipulowanie modelem w taki sposób, by działał on w zmienionej skali w czasie i przestrzeni, umożliwiając w ten sposób uchwycenie wzajemnych oddziaływań, które w innym przypadku byłyby nieuchwytne z powodu ich oddzielenia w czasie i przestrzeni (Sułek, 2010: 196; Berlinger).

Niezbędnym warunkiem przydatności symulacji jest relacja izomorfizmu, jaka powinna zachodzić między modelem i systemem przedmiotowym. Można wówczas wnioskować o dynamice modelowanego systemu na podstawie jego zachowania. Model powinien odzwierciedlać w możliwie wierny sposób system przedmiotowy zależny od charakteru modelu lub prowadzonych badań. W procesie budowy i wykorzystania modelu wyróżnia się dwa etapy: modelowanie i symulację. Pierwszy skierowany jest na: określenie systemu, sytuacji problemowej i celu budowy modelu; budowę modelu (konceptualizacja, formalizacja); przygotowanie danych wejściowych symulacji; programowanie modelu (operacjonalizacja modelu), a w końcu na ocenę zasadności i weryfikację modelu (eksperyment wstępny). Na etap drugi składa się: planowanie eksperymentu symulacyjnego; realizacja eksperymentu symulacyjnego (eksperyment właściwy); analiza i interpretacja wyników symulacji; dokumentowanie symulacji oraz praktyczne wykorzystanie wyników symulacji (Wieleba).

Modelowanie dotyczy zależności (relacji) występujących pomiędzy systemami rzeczywistymi i ich modelami konceptualnymi, natomiast symulacja, jako proces „rozwiązywania" modeli, dotyczy zależności pomiędzy modelami konceptualnymi a modelami operacyjnymi (ibidem). Stąd, nie uda się stworzyć rzetelnych symulacji, bez odpowiednio skonstruowanych modeli.

Z symulacjami spotykamy się bardzo często w opracowaniach dotyczących prognozowania gospodarczego. Mowa wówczas - najczęściej - o ekonometrycznych modelach symulacji procesów. Symulacja na modelu ekonometrycznym wymaga uzyskania w każdym przebiegu symulacyjnym (powtórzeniu eksperymentu, doświadczenia symulacyjnego) rozwiązania tego modelu przy użyciu metod iteracyjnych. Przez rozwiązanie modelu będziemy rozumieć wyznaczenie wartości wszystkich zmiennych 
endogenicznych modelu. Wyróżniamy dwa rodzaje symulacji. Pierwszą nazwiemy symulacją deterministyczną. Występuje ona wtedy, gdy wartości zmiennych egzogenicznych (dla okresu poza próba), parametrów strukturalnych i składników losowych modelu, określone w sposób jednoznaczny poprzez konkretne, punktowe wartości, umożliwiają znalezienie rozwiązania modelu. Drugi rodzaj, czyli symulacja stochastyczna, wystapi wtedy, gdy wartości zmiennych egzogenicznych, parametrów lub składników losowych modelu są generowane zgodnie z wybranymi, w określonym planie eksperymentów, rozkładami prawdopodobieństwa. Symulowane wartości endogenicznych stanów systemu to nic innego jak rozwiązania modelu ekonometrycznego określonej wersji (Prognozowanie, 2002: 163-164).

Jak wskazuje A. Nowak z Instytutu Studiów Społecznych Uniwersytetu Warszawskiego, nauki społeczne mają dwa, pozornie sprzeczne oblicza, a każde z nich wiąże je z innymi metodami zdobywania wiedzy. $Z$ jednej strony nauki społeczne są mocno osadzone w tradycji humanistycznej. Głębia rozumienia zjawisk i procesów, kontekstu kulturowego i historycznego zjawisk społecznych pozwala znaleźć wiele wspólnego między socjologią a historia; analiza przypadków klinicznych czy refleksja humanistyczna zbliża psychologię do filozofii. $Z$ drugiej strony, nauki społeczne mają wiele wspólnego z naukami przyrodniczymi. Badania sondażowe w socjologii, badania eksperymentalne w psychologii i podejście teoretyczne oparte na tradycji empirycznej swe metody dzielą z chemia, biologią czy fizyka, gdzie modelowanie matematyczne i symulacje komputerowe należą do trzonu metod nauk przyrodniczych. Te dwa podejścia - tradycja humanistyczna i przyrodnicza - współistniały w naukach społecznych od dawna, niezbyt się przenikając. Wiedza gromadzona w podejściu humanistycznym zbyt mało była precyzyjna, by dało się ją badać w ścisłym podejściu, a teorie rozwijane w tradycji przyrodniczej, mimo że sprawdzone empirycznie, były zbyt proste i zbyt mało rozumiejące, by poważnie zainteresować badaczy o tradycji humanistycznej. W szczególności modele matematyczne w naukach społecznych były traktowane jako „sztuka dla sztuki”, zabawa formalizmami, demonstracja, że jest możliwy ścisły opis zjawisk społecznych. $\mathrm{Z}$ tego opisu zwykle mało nowych rzeczy wynikało, w szczególności zwykle nie wynikały ani nowe sposoby rozumienia zjawisk społecznych, których nie dałoby się wyrazić bez matematyki, ani nowe zastosowania praktyczne. Jedynym chyba bezspornie użytecznym dla nauk społecznych działem matematyki była statystyka, jako podstawowe i niezbędne narzędzie obliczeń wyników badań empirycznych (Nowak, 2007: 7).

Podobnego zdania jest M. Sułek z Uniwersytetu Warszawskiego, który pisze, iż nauki przyrodnicze, zwłaszcza fizyka i chemia, opierają się w wielkiej mierze na kontrolowanych eksperymentach laboratoryjnych. Nauki społeczne są w innej sytuacji, ale i tu istnieją ograniczone możliwości eksperymentowania (np. w psychologii, socjologii). Gorzej jest w nauce o stosunkach międzynarodowych. Wprowadzenie komputerów po II wojnie światowej stworzyło nowe możliwości zastosowania metod ilościowych w badaniu i nauczaniu, w tym w naukach społecznych. Pojawiły się możliwości eksperymentowania, co prawda tylko na modelach (Sułek, 2010: 198; Modelowanie, 2007).

I choć symulacja kojarzy nam się współcześnie przede wszystkim z symulacjami komputerowymi, warto wspomnieć choć kilka słów o historii gier symulacyjnych, 
a także o symulacjach przeprowadzanych współcześnie metodą „tradycyjną”, w której miast kart graficznych, procesorów etc. używa się „tylko” ludzkich myśli.

Od starożytności znane były gry symulacyjne podejmowania decyzji wojskowych (gry wojenne). W literaturze przywołuje się starożytnych Egipcjan, Sumerów, Chińczyków i Hindusów. Gry te wymagały od graczy, by skupiali się na dobrze określonym celu oraz dokonywali oceny możliwości własnych oraz przeciwników (Sułek, 2010: 198).

Z historii nowożytnej warto przywołać zwłaszcza hrabiego Jamesa Waldegrave'a. Przedstawił on w 1713 r. opis gry w karty o nazwie Le Her. Dwaj gracze ciagną karty z potasowanej talii i ,starsza” z nich wygrywa. Gracz o imieniu Pierre losuje kartę graczowi o imieniu Paul, a potem losuje sobie. Jeśli Paul jest z karty niezadowolony, może zmusić Pierre'a, żeby się z nim zamienił (chyba że Pierre ma króla, czyli kartę zwycięska), a jeśli Pierre jest niezadowolony z wymiany (albo ze swojej pierwszej karty), może wziąć następną kartę z talii. Jeśli jednak wyciagnie króla, musi go zwrócić i pogodzić się z tą, którą miał poprzednio. Wtedy wykładają karty na stół. W przypadku remisu, wygrywa Pierre, bo to on rozdawał (Kaplan, Kaplan, 2008: 250). Podobnie jak w blackjacku, istnieje kilka prostych i niepodważalnych zasad. Paul powinien wymienić każdą kartę niższą od siódemki i zatrzymywać wszystkie wyższe. A co z tymi siódemkami i ósemkami? Tutaj przeciwnik ma pole do działania. Jeśli Paul za każdym razem, gdy wyciaga siódemkę, wymienia ją, Pierre powinien wymieniać ósemki. A jeśli Pierre zawsze wymienia kartę, gdy dostaje ósemkę, Paul zdobywa przewagę, jeśli nie wymienia swojej siódemki. Oto dylemat - jeden z graczy zyskuje przewagę, gdy obydwaj stosują tę samą strategię, a drugi, gdy każdy stosuje inną (ibidem). J. Waldegrave zdawał sobie, że problem nie leży po stronie prawdopodobieństwa, lecz decyzji graczy. Każdy chce mieć większą szansę na wygraną. Każdy chce wygrać pewną sumę i dobrze wie, że wszystko powyżej zależy od łaski człowieka siedzącego po drugiej stronie stołu (ibidem: 251).

Od XVII w. wojskowa wartość gry wojennej była powszechnie uznawana, szczególnie w Niemczech, gdzie nazywaną ją ,grą królewską” (Königsspiel). W końcu XVII w. techniki i modele gier wojennych skomplikowały się i upowszechniły w Europie. Gry wojenne stosowali w latach następnych Helmut von Moltke, Alfred von Schliefen, a od I wojny światowej stały się powszechne. Rozwój komputerów otworzył nowe możliwości przetwarzania informacji, wzbogacając edukacyjne i badawcze walory gier wojennych (Sułek, 2010: 198-199).

Jak zauważa M. Sułek, w politologii gry decyzyjne występują pod takimi nazwami, jak ,gry symulacyjne procesów rządzenia” (ang. government simulation) czy po prostu „symulacje polityczne” (ang. political simulation). Jest to ten typ gier starających się symulować rządzenie w skali całego kraju bądź jego części. Gry decyzyjne (nazywane także grami symulacyjnymi, symulacyjnymi grami decyzyjnymi, grami kierowniczymi, grami wojennymi, grami obronnymi, grami strategicznymi etc.) są rodzajem eksperymentu na modelu symulacyjnym. Uczestnicy eksperymentu odgrywają role przewidziane scenariuszem gry, które wymagają od nich podejmowania decyzji, oceniania ich skutków i formułowania wytycznych lub podejmowania decyzji w następnych okresach. Gry symulacyjne stosuje się w badaniach naukowych, w podejmowaniu decyzji, jak i w procesie szkolenia menedżerów czy dowódców (ibidem: 202-203). 


\section{GRY DECYZYJNE/ SYMULACYJNE ORAZ SIECIOWE}

Nim wskazane zostaną przykłady wykorzystania - lub współwykorzystania - komputerów w symulacjach, wpierw omówimy przykład „tradycyjnej” gry decyzyjnej o celach głównie dydaktycznych. Jest to Model United Nations (MUN, Model ONZ) - młodzieżowa inicjatywa polegająca na edukacji politycznej przez symulację obrad Organizacji Narodów Zjednoczonych. Podczas wielogodzinnych obrad przedstawiciele wybranych przez siebie państw (obowiązuje zakaz reprezentowania własnego kraju) debatują m.in. nad problemami światowego głodu, niedostatecznej edukacji, terroryzmu, klęsk żywiołowych. W Polsce Model United Nations organizuje się od $1991 \mathrm{r}$. w Gorzowie Wielkopolskim, w Warszawie od 2006, Szczecinie od 2012 r. (ibidem: 205-206; Kardasz, 2011; Warsaw; StetiMUN2013).

2-5 maja 2013 r. symulacja taka odbyła się po raz pierwszy w Poznaniu, na Wydziale Nauk Politycznych i Dziennikarstwa Uniwersytetu im. Adama Mickiewicza (autor niniejszej publikacji był osobą współodpowiedzialną za przygotowanie tego wydarzenia). Był to Poznań International Model United Nations 2013 - POZiMUN. Konferencja opierała się na jak najbardziej realnej i rzetelnej symulacji pracy wyspecjalizowanych jednostek ONZ (Rada Bezpieczeństwa, Wysoki Komisarz Narodów Zjednoczonych ds. Uchodźców, Rada Praw Człowieka). Uczestnicy od Sekretariatu POZiMUN otrzymali odpowiednio wcześnie materiały, które miały im pomóc w przygotowaniu do konferencji. Dydaktyczno-szkoleniowy charakter symulacji miał za zadanie zwrócenie uwagi na wybrane problemy współczesnego świata oraz sposoby i możliwości ich rozwiązania. Rozpatrywano m.in. następujące problemy: 1) konflikt w Beludżystanie; 2) pokój i stabilizacja w regionie Tuaregów w Afryce Północnej; 3) zagubieni w mieście - urban refugees; 4) Haiti po wygaśnięciu zainteresowania medialnego; 5) prawo do wody jako podstawowe prawo człowieka; 6) naruszenia praw człowieka w Bahrajnie.

Zadaniem każdego z delegatów było wcielenie się w rolę reprezentanta jednego z państw członkowskich ONZ i stworzenie adekwatnego stanowiska politycznego na dyskutowany temat. W symulacji czynny udział wzięło blisko 50 osób (z 16 państw); kolejnych kilkanaście było zaangażowanych $\mathrm{w}$ zorganizowanie oraz obsługę obrad. Aby obrady miały jak najbardziej realistyczny charakter delegaci musieli zapoznać się z polityką prowadzoną aktualnie przez wszystkich członków ich komisji. Następnie toczona była moderowana przez Przewodniczących dyskusja, której celem było stworzenie wspólnej rezolucji lub rekomendacji. Rekomendacja i rezolucja musiały być zgodne ze standardami ONZ i były edytowane przez Sekretarza Generalnego konferencji. Całość obrad odbywała się w języku angielskim.

W toku Poznań International Model United Nations 2013 osiągnięto zamierzone cele, tj.:

- zapoznanie z procedurami i działaniami odpowiednich jednostek ONZ;

- zapoznanie z regułami tworzenia rezolucji i rekomendacji ONZ;

- zapoznanie z odpowiednim słownictwem i warunkami prowadzenia dyskusji w ramach sesji ONZ;

- przybliżenie delegatom współczesnych problemów globalnych i lokalnych oraz możliwości ich rozwiązania;

- poszerzenie wiedzy dotyczącej istoty dyskutowanych problemów; 
- zapoznanie z mechanizmami, kierującymi globalną polityką, organizacjami międzynarodowymi oraz poszczególnymi państwami;

- zaznajomienie uczestników z zasadami i mechanizmami negocjacji oraz możliwościami ich wykorzystania.

Warto też podkreślić, że w przypadku takich symulacji zazwyczaj wprowadza się również w trakcie obrad tzw. czynnik zakłócający (np. informuje o nagle rozpoczętym konflikcie itd.), który utrudnia pracę uczestnikom obrad. Wszystko po to, by jak najwierniej oddać świat rzeczywisty, pełen takich zdarzeń. Dlaczego? Gdy mówimy o symulacjach międzynarodowych (ale odnosi się to także do jakichkolwiek zjawisk czy procesów), to musimy pamiętać, że badany model jest elementem dynamicznym funkcjonującym w rzeczywistości międzynarodowej. Z tego względu należy liczyć się z istnieniem czynników zakłócających wpływających na obiekt w sensie pozytywnym jak i negatywnym. Zdarzeniem zakłócającym jest zdarzenie, które choć występuje nagle nie ma charakteru katastrofy. Musimy zatem ocenić wpływ takich zdarzeń na rozwój obiektu oraz określić czynności przeciwdziałające (gdy zdarzenie ma charakter negatywny), lub przystosowawcze (w przypadku pozytywnego wpływu czynników zakłócających badany obiekt) (Stryjski, 2004: 78).

Jak wspomniano, przewidywanie zjawisk społecznych (w sensie globalnym) utrudnia (oprócz innych czynników) m.in. rozwojowy charakter rzeczywistości społecznej - rzeczywistość, w której żyjemy radykalnie się zmienia. Dzieje wymagają uzupełnienia wiedzy ogólnej o nowe informacje dotyczące nowych epok. Wiedza ogólna ma więc małą przydatność, sama w sobie musi być nasycona nowymi informacjami. Musi być więc uwzględniona nowa wiedza - konkretna, historyczna aby dalej przewidywać (Materials; Karwat, 2009: 175). Częste przejawy chaotyczności zmian i nieokreśloności sytuacji decyzyjnych mogą być efektem rosnącej złożoności systemu globalnego. Dowodem na to mogą być zjawiska określane mianem Black Swan (Lamentowicz, 2012: 56). Czym one są? Otóż przez całe wieki na terenach Europy utrzymywało się przekonanie, że wszystkie łabędzie są białe. Co więcej, funkcjonowało nawet powiedzenie, że coś jest tak oczywiste jak to, że wszystkie łabędzie są białe. Taki stan rzeczy utrzymywał się mniej więcej do XVII wieku, kiedy to duńscy badacze odkryli nowy kontynent - Australię, a wraz z nią nowe gatunki roślin i zwierząt. Wśród tych ostatnich szczególną uwagę przykuły łabędzie, których upierzenie było koloru czarnego. Warto zastanowić się nad tym wydarzeniem. Otóż, przez stulecia każda pojedyncza obserwacja potwierdzała pogląd dotyczący koloru łabędzi. Ale wystarczył tylko jeden jedyny przypadek obserwacji dokonanej na nieznanym ówczesnej cywilizacji obszarze, aby zburzyć całe milenia ciągłych potwierdzeń przekonania, że „wszystkie łabędzie są białe". Odkryty w Australii łabędź okazał się być czymś nieprawdopodobnym, niespodziewanym, czy wręcz niemożliwym. O czarnym łabędziu zrobiło się głośno za sprawą N. N Taleba - finansisty i inwestora z Wall Street, którego matematyczne oraz filozoficzne zamiłowania zaprowadziły do zaciętej krytyki funkcjonowania banków, biur maklerskich, funduszy inwestycyjnych oraz wielu innych instytucji finansowych. W książce zatytułowanej Black Swan. The impact of the Highly Improbable (Taleb, 2007) wytłumaczył owo pojęcie w sposób następujący: jest to pewne zdarzenie, które posiada trzy właściwości: 1) jest ono z gruntu nieprzewidywalne, a przynajmniej prawdopodobieństwo jego zajścia możemy oszacować jako skrajnie niskie; 2) niesie ze sobą 
olbrzymie konsekwencje; 3) posiada retrospektywny charakter tzn. zawsze po zajściu takiego zdarzenia, doszukujemy się jego przyczyn, czyniąc je przewidywalnym i wytłumaczalnym (w naszym mniemaniu) (Malinowski; Taleb, 2007; Taleb, 2009).

Wracając do symulacji z wykorzystaniem najnowszych zdobyczy techniki - w Polsce takowe prowadzi m.in. usytuowane przy Akademii Obrony Narodowej Centrum Symulacji i Komputerowych Gier Wojennych (CSiKGW). Powstało ono w wyniku realizacji zobowiązań sojuszniczych w ramach działań integrujących (w obszarze szkolenia operacyjnego z wykorzystaniem systemów symulacyjnych) Siły Zbrojne RP z armiami państw NATO. Centrum jest instytucją zajmującą się organizacją ćwiczeń wspomaganych komputerowo (ang. Computer Assisted Exercise - CAX) oraz wdrażaniem i wykorzystaniem systemów symulacyjnych w wielu dziedzinach działalności militarnej Centrum Symulacji i Komputerowych Gier Wojennych ściśle współpracuje w zakresie zastosowań systemów symulacyjnych działań bojowych w procesie szkolenia sił zbrojnych z podobnymi placówkami państw NATO (Centrum).

Podkreślić należy, że umiejętne wykorzystanie militarnych systemów symulacyjnych to skomplikowany proces, w którym uczestniczy wiele podmiotów, z którym wiążą się także pewne modyfikacje dotyczące procedur, doktryn, programów szkolenia, organizacji ćwiczeń, itd. Symulacja w siłach zbrojnych, ze względu na specyfikę ich działalności, znajduje zastosowanie w wielu obszarach. Na przykład metody symulacyjne z powodzeniem mogą być stosowane do projektowania, testowania i modyfikowania systemów walki. Również wykorzystanie systemów symulacyjnych w ćwiczeniach wspomaganych komputerowo uważane jest za bardzo skuteczną i ekonomicznie korzystną formę szkolenia dowództw i sztabów wszystkich szczebli dowodzenia, która pozwala na pogodzenie złożoności i dynamiki współczesnych działań militarnych oraz utrzymującej się tendencji do redukcji nakładów na obronność z wysoką jakością szkolenia (ibidem).

Z aktualnych inicjatyw prowadzonych przez CSiKGW wymienić można chociażby projekt Modelowanie i symulacja architektury systemu obrony przed bronia masowego rażenia (MaSC). Projekt ten realizowany będzie przez międzynarodowe konsorcjum, które we wrześniu 2012 wygrało konkurs w ramach programu Europejskiej Agencji Obrony - JIP CBRN PROTECTION ukierunkowanego na uzyskanie rozwiązań o niskim poziomie zaawansowania technologicznego. Liderem zwycięskiego konsorcjum jest holenderska firma TNO, która we współpracy z Akademią Obrony Narodowej reprezentowaną przez CSOPBMR oraz WBN, polską firmą ITTI posiadającą olbrzymie doświadczenie w realizacji projektów pod auspicjami Europejskiej Agencji Obrony, a także pozostałymi partnerami: francuską firmą THALES i belgijską Królewską Akademią Wojskową przez 24 miesiące będzie prowadzić prace nad uzyskaniem zamierzonego produktu - zintegrowanego rozwiązania informatycznego umożliwiającego w oparciu o modelowane scenariusze zagrożeń przeprowadzenie symulacji potrzeb sił i środków oraz doboru optymalnego sposobu rozwiązania w ramach wsparcia procesu planowania działań w warunkach zagrożenia skażeniami (Modelowanie).

Pisząc o CSiKGW nietaktem byłoby pominięcie gry symulacyjnej Strategic Economic Needs and Security Simulation Exercise (S.E.N.S.E.). Jest to gra strategiczna symulującą zjawiska polityczne, społeczne, ekonomiczne oraz aspekty związane z bezpieczeństwem narodowym. Procesy te zachodzą w fikcyjnym państwie o nazwie Akrona 
(patrz: mapa 1). To nieistniejące w rzeczywistym świecie państwo ukształtowało się w wyniku przemian społeczno-politycznych w bliżej nieokreślonym rejonie świata. Kraj ten zmaga się z typowymi problemami dotykającymi także realnie istniejące państwa, które znajdują się w trakcie transformacji ustrojowej, ekonomicznej lub które niedawno odzyskały suwerenność. Nie istnieje jednak żadne wyraźne nawiązanie do sytuacji w którymś z krajów Europy środkowo-wschodniej, państw powstałych po rozpadzie Jugosławii, czy też Iraku i Afganistanu. Zadaniem uczestników gry jest wcielenie się w funkcjonujące w kraju organy władzy wykonawczej i ustawodawczej oraz rozwiązywanie stojących przed tymi organami wyzwań. Wyzwania te to przede wszystkim: istniejące konflikty etniczne, rozwój ekonomiczny oraz budowa stabilności politycznej. Państwo Akrona nie istnieje jednak w próżni. Gra uwzględnia także instytucje międzynarodowe oraz organizacje pozarządowe, których zadaniem jest wspieranie rządu Akrony w rozwiązywaniu istniejących problemów. Wszystkie problemy rozwiązywane są $\mathrm{w}$ drodze negocjacji, współpracy oraz wymiany informacji pomiędzy poszczególnymi uczestnikami gry. Wypracowane wspólnie decyzje zostają wprowadzone do modelu symulacyjnego, którego zadaniem jest zastapienie, nieobecnego w rzeczywistości, środowiska społeczno-ekonomicznego, na które składają przedsiębiorstwa i instytucje 24 sektorów gospodarki narodowej (Boryń, Obłoza).

Pomysłodawcą przedsięwzięcia jest generał Wesley Clark. Jako głównodowodzący wojskami NATO w Europie w okresie intensywnych przemian polityczno-ekonomicznych dostrzegł potrzebę wspierania przez rząd USA „,młodych demokracji” nie tylko w Europie, ale również na Bliskim Wschodzie. Owocem pomysłu jest projekt S.E.N.S.E., który przygotowany został przez Institute for Defense Analyses - IDA. Od 2006 r. Ministerstwo Spraw Zagranicznych (MSZ) przy współpracy z Uniwersytetem Warszawski oraz CSiKGW Akademii Obrony Narodowej zorganizowało cykl szkoleń w ramach programu S.E.N.S.E. Sprawy organizacyjne powyższego programu powierzone zostały Studium Europy Wschodniej UW, a szkolenia odbywały się w CSiKGW (ibidem; SENSE, 2006). Taka formuła organizacji szkoleń obowiązywała do końca 2008 r. Od roku 2009 wszystkie sprawy związane z organizacją ćwiczeń spoczywają na MSZ, które współpracuje w tej kwestii z CSiKGW. Zmieniła się również formuła szkoleń. Uczestnicy ćwiczenia przed przystapieniem do „rządzenia” państwem Akrona przechodzą cykl szkoleń, których celem jest zapoznanie ich z technikami negocjacji i metodami rozwiązywania konfliktów, które ułatwiają osiągnięcie sukcesu w prowadzeniu rozmów z pozostałymi uczestnikami szkolenia (Boryń, Obłoza).

Program szkoleń przygotowano we współpracy MSZ, CSiKGW Akademii Obrony Narodowej oraz United States Institute for Peace (USIP). Celem szkolenia jest rozpoznanie i zrozumienie przez uczestników współzależności panujących w systemie państwowym (w aspekcie politycznym, społecznym, jak i ekonomicznym). Kluczowym dla szkolenia jest by wiedzę i umiejętności uczestnicy szkolenia oparli na doświadczeniu wyniesionym z przeprowadzonej symulacji. Uczestnikami szkolenia na ogół są osoby, które w przewidywalnej przyszłości uczestniczyć będą w realnej transformacji ustrojowo-ekonomicznej w swoich państwach. Uczestnicy szkolenia podczas trwania symulacji przenoszą się do wirtualnego państwa (ibidem).

Symulacja dostarcza ekonomicznych (realistycznych) doświadczeń. W trakcie symulacji modelowane są zarówno sektory prywatne, jak i publiczne. Obecna wersja 
oprogramowania wspiera 24 sektory ekonomiczne. Wszystkie sektory łączy gospodarka międzynarodowa. W procesie symulacji można wyróżnić osiem typów graczy pracujących w 14 podgrupach. Podział ten wraz z liczbą ćwiczących wchodzących w skład poszczególnych grup przedstawia rysunek 3 wraz z opisem (ibidem).

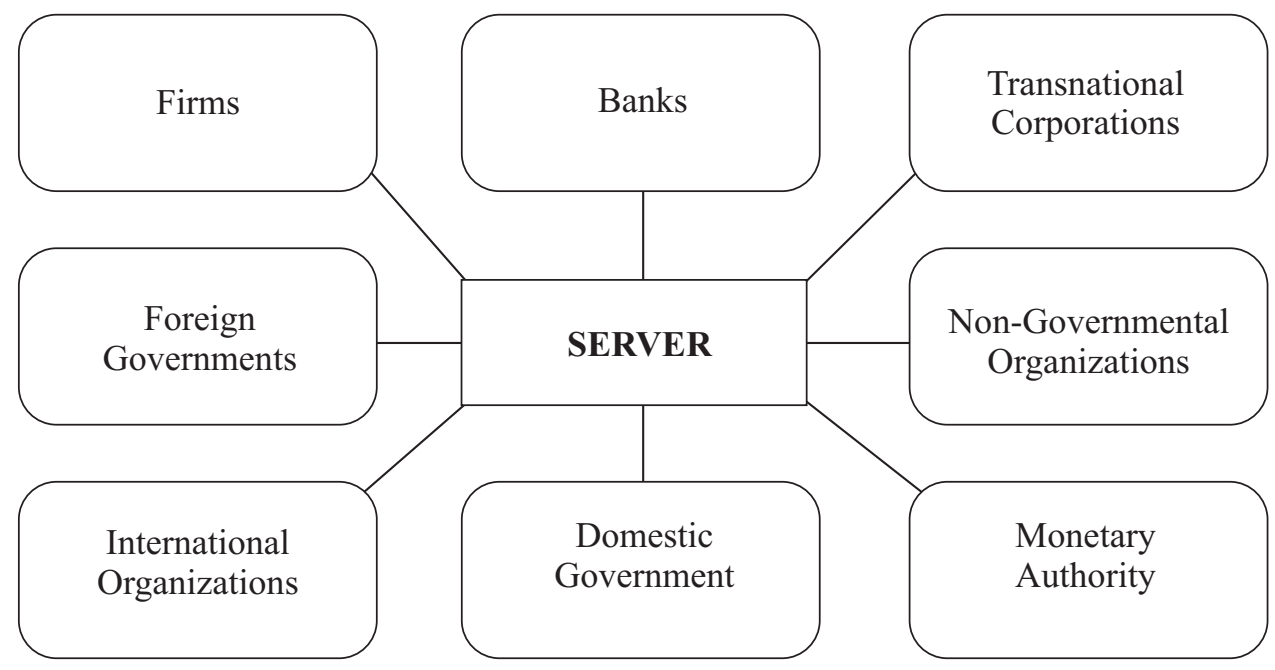

Rys. 3. Organizacja ćwiczących

Źródlo: P. Boryń, W. Obłoza, S.E.N.S.E., http://www.csikgw.aon.edu.pl/index.php/pl/modelowanie/102-sense.html (31.07.2013).

Gdzie:

- Firms (19 ćwiczących): firmy reprezentujące interesy sektora prywatnego;

- Banks (4 ćwiczących): banki dostarczające kapitał (przy cenach rynkowych);

- Transnational Corporations (2 ćwiczących): międzynarodowe korporacje reprezentujące interesy inwestorów zagranicznych oraz pożyczkodawców;

- Foreign Governments (2 ćwiczących): rządy zagraniczne dostarczające wsparcia ekonomicznego, jak i militarnego;

- Non-Governmental Organizations (1 ćwiczący): organizacje reprezentujące interesy pozarządowe;

- International Organizations (1 ćwiczący): organizacje reprezentujące interesy banków światowych;

- Domestic Government (18 ćwiczących): rząd, który zarządza budżetem cywilnym, militarnym oraz posiada zdolność działania w zakresie udzielania jak pożyczania środków finansowych;

- Monetary Authority (2-4 ćwiczących): komórka reprezentująca bank centralny oraz prowadząca kontrolę nad przepływem pieniądza, stopami procentowymi oraz zajmująca się oceną waluty (ibidem).

Bardzo ważnym elementem symulacji jest upływ czasu, który odbywa się w tzw. okresach (ang. period). Czas ten nie jest równy czasowi astronomicznemu. Jeden okres odpowiada miesiącowi. W systemie istnieje osoba funkcyjna określana mianem Game Master, która kontroluje przebieg procesu symulacji i ustala prędkość gry - szybkości 
zmiany okresów. Dla początkujących uczestników czas trwania jednego okresu (jednego miesiąca) ustala się na 300-450 sekund, a wraz z nabieraniem przez uczestników symulacji doświadczenia czas trwania jednego okresu zostaje zmniejszony. Aplikacja służąca do symulacji ekonomicznej wykonana została według architektury klient - serwer, a architektura oprogramowania przygotowana jest do pracy w systemie operacyjnym Windows $X P$ w wersji angielskiej (ibidem).

Gracze komunikują się z serwerem przez interfejs, którego narzędzia pozwalają na podejmowanie działań oraz śledzenie skutków ich realizacji. Rezultaty działań użytkowników przedstawiane są w formie tabelarycznej oraz graficznej (wykresy). Zawierają one aktualne dane dotyczące wartości, rentowności i społecznych skutków realizowanych inwestycji. System, wykorzystując zapisane dane, pozwala na wnikliwą analizę skutków podjętych przez ćwiczących decyzji (platforma bazodanowa wymagana dla oprogramowania S.E.N.S.E. wykorzystuje system ORACLE $10 g$ ). Po zakończeniu procesu symulacji odbywa się omówienie i podsumowanie działań użytkowników. Wykorzystywane jest do tego specjalny moduł After Action Review (AAR), w który wyposażony jest program. Oprogramowanie to wykorzystuje dane zapisane podczas symulacji w bazie danych, co pozwala na dogłębną analizę podjętych przez ćwiczących działań (ibidem).

Wraz z rozwojem Internetu, zwłaszcza z dostępem do Internetu szerokopasmowego wzrosło zainteresowanie grami sieciowymi. Można by długo pisać, dlaczego ludzie w gry w ogóle grają. Nas interesować będą zwłaszcza dwie kwestie: po pierwsze - ludzie grają by wygrać, by osiagnąć cel, tak samo jak w interakcji interesownej widzianej oczami teorii racjonalnego wyboru. Istnieje jednak i drugie oblicze gry, które można nazwać nie-racjonalnym. Wówczas, jak w interakcji nieinteresownej, liczy się po prostu przyjemność z samego grania (Wróblewski, 2009: 292).

Czym jednak jest sama gra? Będzie to - w rozumieniu teorii gier - logiczna analiza sytuacji konfliktu i kooperacji. O grze będziemy więc mówić wszędzie tam, gdzie:

1) można wskazać co najmniej dwóch graczy. Graczem może być człowiek, ale także firma, państwo, czy nawet gatunek w znaczeniu biologicznym;

2) każdy gracz ma do wyboru pewną liczbę możliwych strategii, określających sposób rozgrywania przez niego gry;

3) wynik gry jest determinowany przez kombinację strategii wybranych przez poszczególnych graczy;

4) każdemu możliwemu wynikowi gry odpowiada zestaw wypłat dla poszczególnych graczy, których wysokość można wyrazić liczbowo (Straffin, 2011: 1).

Teoria gier bada, jak gracze powinni racjonalnie rozgrywać grę. Każdy z nich powinien dążyć do takiego jej zakończenia, które daje mu możliwie najwyższą wypłatę. Gracz wpływa na przebieg gry, wybiera swoją strategię; ostateczny wynik zależy jednak nie tylko od niego, ale także od decyzji pozostałych uczestników - i właśnie tutaj jest miejsce na konflikt i kooperację. Konflikt - ponieważ zwykle każdy z graczy dąży do innego wyniku gry. Są jednak sytuacje, gdy kilku graczy koordynując swoje strategie może doprowadzić do wyniku dającego każdemu z nich wyższą wypłatę i wtedy możliwa jest kooperacja. Racjonalna rozgrywka wymaga, by każdy gracz, decydując o wyborze strategii mającej mu przynieść korzystny rezultat, uwzględniał prawdopodobne decyzje pozostałych graczy - dążących do wyników korzystnych dla 
siebie. Istotne są także decyzje społeczne - kto, z kim i jak będzie kooperował (ibidem: 1-2).

EVE Online to symulator statku kosmicznego w konwencji MMO (ang. Massive Multiplayer Online) czyli takiej, gdzie tysiące osób na raz grają z sobą przez internet, wzbogacony o szerokie możliwości ekonomiczne i wojenne. Olbrzymi świat oferuje nie tylko możliwość staczania bitew i rozwoju postaci, ale przede wszystkim rozwijanie własnego imperium za pomocą handlu czy produkcji nowych technologii (EVE; Poradnik). Inflacja, deflacja, a nawet recesja - wszystko się może zdarzyć. EVE Online został stworzony przez islandzką firmę CCP Games w 2003 r., a nad procesami ekonomicznymi w symulatorze nadzór sprawuje zatrudniony przez firmę ekonomista E. Gudmundsson. Kieruje on zespołem ośmiu analityków ślęczących nad górami danych, by się upewnić, że wszystko w grze przebiega bez zakłóceń. E. Gudmundsson nie jest wyjątkiem wśród ekonomistów. Wielu specjalistów od ekonomii chętnie zajmuje się badaniem gier wideo. W wirtualnych światach mogą studiować modele, które rzadko są stosowane w realnym życiu. Może to zrewolucjonizować ekonomię. Zdaniem greckiego ekonomisty J. Warufakis: „Teoria ekonomiczna znalazła się obecnie w martwym punkcie - ostatnie przełomowe nowinki pochodzą z lat $60 \mathrm{XX}$ w. W przyszłości trzeba będzie eksperymentować i przeprowadzać symulacje, a społeczności uczestników gier wideo stwarzają nam taką możliwość". W czerwcu 2012 r. ogłosił na swoim blogu, że został zatrudniony przez firmę Valve, twórcę serii gier wideo Half-Life (Inflacja).

Gospodarka EVE Online podlega wielkim wahaniom. Dlatego ekipa specjalistów musi okresowo regulować nierównowagę podaży pieniądza. Może np. ograniczyć inflację poprzez wprowadzenie nowego typu broni, by wchłonąc nadmiar wirtualnej waluty - trochę na wzór banku centralnego sprzedającego obligacje. Nadzorcy gry regularnie wprowadzają nowe technologie albo zmiany w dostępności do niektórych surowców, by podtrzymać zainteresowanie uczestników, co daje te same efekty, co przełomy technologiczne mające miejsce w realnym świecie. Gracze często starają się przewidzieć te modyfikacje. E. Gudmundsson wskazał, że: „Zaobserwowaliśmy [...] tworzenie karteli w celu manipulowania rynkiem, kontrolowania dostaw i wpływania na poziom cen. To bardzo przypomina OPEC". W pewnym sensie gospodarka EVE Online jest libertariańskim eksperymentem w dużej skali. Obowiązuje tam niewiele regulacji. Rynki szybko odbijają się od dna po recesji, bo nie ma płacy minimalnej i innych ograniczeń. Gracze mogą łączyć swoje siły, by np. tworzyć wielkie przedsiębiorstwa, sojusze handlowe i instytucje finansowe. Banki w EVE Online nie są wspierane przez bank centralny, czyli pożyczkodawcę ostatniej instancji, i nie są zobowiązane do tworzenia rezerw. Muszą być sumienne i skuteczne - wyjaśnia E. Gudmundsson. Wystawia to jednak na ryzyko cały system. Bank zbankrutował w 2009 r., kiedy to jego założyciel zagarnął wirtualne fundusze, by wymienić je na prawdziwe pieniądze na swoistym czarnym rynku. Gdy sprawa wyszła na jaw, uczestnicy zaczęli masowo wycofywać depozyty i wirtualna instytucja musiała ogłosić upadłość (ibidem).

W grach, jak i w życiu zdarzają się sytuacje przypadkowe, wydawać by się mogło nieprzewidywalne, a już z pewnością nieracjonalne. Podobnie było nie raz w EVE Online. W styczniu 2013 r. gracze $\mathrm{z}$ dwóch wrogich sojuszów szykowali się do starcia w mało znaczącym układzie planetarnym. Część z nich miał przetransportować na 
miejsce pilot największego statku w grze - Tytana. Osoba siedząca za sterami wirtualnego giganta popełniła jednak mały, ale bardzo kosztowny błąd. Zamiast kliknąć w ikonkę tworzącą specjalny korytarz umożliwiający jego kolegom dołączenie do niego z odległego układu planetarnego, kliknął w sąsiednią ikonkę, która spowodowała, że jego statek wykonał „skok” prosto w środek wrogiej floty. Gdy zaskoczeni gracze zobaczyli lądujący im na głowie najdroższy statek w ich wirtualnym świecie, natychmiast przystapili do ataku i zaczęli wzywać pomocy. Samotny pilot Tytana również wezwał sojuszników, bowiem znalazł się w ciężkiej sytuacji. Nie mógł uciec i mógł stracić warty tysiące dolarów statek, będący efektem pracy setek graczy. Do mało znaczącego systemu Asakai zaczęło coraz bardziej wartkim strumieniem zmierzać wsparcie dla obu stron. Szybko naprzeciw siebie stanęły główne siły dwóch wrogich sojuszy wirtualnego świata EVE: ClusterFu** Coalition i HoneyBadger Coalition, rozpoczynając się rzeź „kosmicznych” okrętów. W trwającej kilka godzin wielkiej bitwie wzięło udział łącznie ponad trzy tysiące ludzi. Konkretna liczba nie jest znana, ze względu na wielkie zamieszanie towarzyszące chaotycznej walce. W ogniu wirtualnych laserów i dział eksplodowało około 900 okrętów, w tym wiele Tytanów i innych największych statków świata $E V E$. Straty podliczane tuż po tym wydarzeniu szacowano na około 830 miliardów ISK, czyli waluty świata EVE. To około 28 tysięcy prawdziwych dolarów (Kucharczyk).

Jak widać z powyższego, gry sieciowe takie jak EVE Online (ale także Second Life, Allods Online, Habbo) mogą stanowić odzwierciedlenie rzeczywistego świata. Jest to oczywiście odzwierciedlenie z jednej strony wyolbrzymione (ograniczone często tylko fantazją gracza), z drugiej ... uproszczone, gdyż, dla przykładu, ,gospodarkami” w tych grach zarządzają często ludzie o konkretnych poglądach ekonomicznych. Trzeba jednak uczciwie przyznać, że i w realnym świecie również zauważalny jest wpływ poszczególnych jednostek/grup na gospodarki narodowe, na gospodarkę światową. Przykładem może być chociażby blisko 20-letni okres kierowania Systemem Rezerwy Federalnej Stanów Zjednoczonych przez A. Greenspana (McTague’s).

\section{TEORIA GIER A PROBLEMY REALNEGO ŚWIATA}

Gry w realnym świecie sąjednak o wiele bardziej skomplikowane niż gry sieciowe. Zarówno jednak w jednym, jak zwłaszcza drugim przypadku, przewidzenie jak będą zachowywać się gracze jest zadaniem awykonalnym (acz, warto zaznaczyć, że również w nauce zastosowanie ma stare powiedzenie ,nigdy nie mów nigdy”). Kompletna teoria racjonalnego rozgrywania gier miałaby bardzo szerokie zastosowanie: mogłaby wskazać najwłaściwszy sposób postępowania w każdej sytuacji konfliktu i kooperacji. Póki co jednak cele teorii gier są znacznie skromniejsze. Istnieją co najmniej trzy powody, dla których tak ogólna teoria gier nie jest możliwa. Po pierwsze, jak już powiedziano, gry rozgrywane w rzeczywistym świecie są zwykle bardzo skomplikowane: trudno wskazać w nich wszystkich graczy, dokładnie opisać ich możliwe strategie i wskazać, do jakich wyników prowadza, trudno jest także przypisać do poszczególnych wyników wartości wypłat. Daje się jedynie skonstruować proste gry, modelując niektóre istotne elementy rzeczywistości, ale samo tworzenie i analiza takich modeli może nam coś o tej rzeczywistości powiedzieć (Straffin, 2011: 2). 
Drugi problem polega na tym, iż teoria gier zakłada, że gracze zachowują się racjonalnie. Każdy z nich analizuje grę w poszukiwaniu sposobu uzyskania pożądanego wyniku, uwzględniając fakt, że pozostali gracze robią to samo - inaczej mówiąc, racjonalny gracz zakłada, że jego przeciwnicy także postępują racjonalnie; $w$ realnym świecie rzadko kiedy można to powiedzieć o wszystkich uczestnikach gry. Z drugiej strony, kwestia, w jakim stopniu uczestnicy sytuacji konfliktu i kooperacji postępują racjonalnie, sama w sobie jest interesująca, a właśnie teoria gier daje narzędzia pozwalające to ocenić (ibidem).

Trzecim i chyba najpoważniejszym ograniczeniem jest fakt, że teoria gier nie potrafi dokładnie przewidzieć przebiegu gier, w których interesu obu graczy nie są dokładnie przeciwstawne, a także takich, w których udział bierze więcej niż dwóch graczy. Dla takich gier istnieje szereg rozwiązań cząstkowych, przykładów, analiz i pomysłów (ibidem).

Wydaje się, że zbyt optymistyczne są sądy wyrażane przez wspomnianego prof. A. Nowaka, o tym, że nowe odkrycia związane z modelowaniem matematycznym i symulacjami komputerowymi zlikwidowały w naukach społecznych pozorną sprzeczność między głębią rozumienia a precyzją opisu zjawisk społecznych. Stało się tak - zdaniem A. Nowaka - dzięki wielu odkryciom związanym z tym, skąd bierze się złożoność procesów i zjawisk w przyrodzie. Te odkrycia dokonane w różnych naukach, głownie w fizyce, pokazały, że złożoność jest drugą stroną medalu prostoty, a nie jej przeciwieństwem. Odkrycie, że bardzo złożone właściwości mogą być wynikiem bardzo prostych zasad jest jednym z najważniejszych odkryć współczesnej nauki. Tak więc układ kilku względnie prostych równań może wykazywać niezwykle złożoną dynamikę w czasie, gdzie przewidywanie staje się niemożliwe, zbiór niezwykle prostych elementów - sztucznych neuronów - połączonych ze sobą może dawać w efekcie ogromnie złożony system poznawczy zdolny do uczenia się na podstawie doświadczenia, generalizacji i rozpoznawania trudno definiowalnych kształtów i wzorów, takich jak pismo ręczne czy mowa. Bardzo proste reguły wzajemnego oddziaływania między ludźmi pozwalają na powstanie bardzo złożonych procesów społecznych. Złożoność jest narzucającą się charakterystyką procesów poznawczych, ludzkich zachowań, funkcjonowania grup i organizacji oraz procesów zachodzących w społeczeństwach. Zrozumienie tego, jak proste zasady mogą dawać w efekcie ogromną złożoność, umożliwiło budowanie prostych modeli złożonych zjawisk, a więc opisywanie w ścisły, a jednocześnie prosty sposób zjawisk społecznych bez rezygnacji z głębi ich rozumienia. Modelowanie matematyczne i symulacje komputerowe są podstawowymi narzędziami, dzięki którym jest to możliwe (Nowak, 2007: 8).

Zgodzić się należy jednak co do jednego: każdy dzień przynosi nam kolejne doświadczenia, kolejne rady. Niezwykle inspirujący może być zwłaszcza rozwój technologii komputerowych. Wymienić należy tu m.in. prace nad fizyką kwantową i stworzeniem komputerów kwantowych (Głowacka; Kubity). Dla potrzeb niniejszego artykułu zbędne jest opisywanie złożoności fizyki kwantowej, dość powiedzieć, że może ona wskazać nam nowe podejście do problemów wielokrotnie rozpatrywanych z punktu widzenia teorii gier. Mowa chociażby o tzw. dylemacie więźnia. Jest to sytuacja, w której występują dwie strony. Zawarły one porozumienie, w wyniku czego mają do wyboru dwie strategie, albo dotrzymać zawartej umowy albo oszukać partnera. Dylemat więźnia po- 
lega na tym, że powstaje sytuacja, w której oszustwo jednej strony daje jej znacznie większy zysk niż w przypadku przestrzegania postanowień umowy, jednakże oszustwo obu stron jednocześnie obniża ich korzyści tak, że stają się one mniejsze, niż w sytuacji obustronnego przestrzegania ustalonych zasad (Dylemat). W klasycznej wersji ów dylemat wygląda na następująco: graczami są dwaj aresztanci, podejrzewani o wspólne popełnienie przestępstwa, przesłuchiwani w osobnych pokojach. Prokurator oświadczył każdemu z nich, że:

- jeśli jeden (A - Alicja) z nich się przyzna, zaś drugi (B - Bob) nie, przyznający się zostanie nagrodzony, zaś jej wspólnik dostanie wysoki wyrok;

- jeśli obaj się przyznają, dostaną łagodne wyroki.

$\mathrm{Z}$ drugiej strony, obaj więźniowie dobrze wiedza, że jeśli żaden z nich się nie przyzna, obaj zostaną uwolnieni (ibidem; Straffin, 2011: 94).

W 1980 r. urządzono zawody między pojedynczymi programami komputerowymi, które rozwiązywały powyższy dylemat. Punkty przyznawano na podstawie wyników. Po trzy dla każdego graczy za obopólną współpracę, po jednym za obopólną odmowę, pięć za odmowę jednej strony i zero za współpracę, gdy partner jej odmówił. Spośród 14 uczestników pierwszego turnieju i 64 drugiego wygrał jeden z najprostszych: „wet za wet", który w pierwszej rundzie wybrał współpracę z partnerem, a potem konsekwentnie robił to, co tamten jemu w poprzedniej rundzie. W tym elektronicznym społeczeństwie ,wet za wet” to solidny obywatel, który - pisząc potocznie - „,nie da sobie wcisnąć kitu”. Możesz go oszukać, ale tylko raz; jeśli zaś będziesz postępować wiarygodnie, będzie postrzegał cię jako dobrego. Jak często mawiają mądrzy ludzie - „mam nadzieję na najlepsze, a przygotowuję się na najgorsze” (Kaplan, Kaplan, 2008: 282).

W powyższym zastosowano zasady logiki klasycznej. Tymczasem lepszym modelem ludzkich zachowań może być mechanika kwantowa, która większy nacisk kłaść może na ludzką skłonność do altruizmu i współpracy. Ostatnio prowadzone badania pokazują że fizyka kwantowa dostarcza modelu ludzkich zachowań, w którym pozorna nieracjonalność, jak najbardziej ma sens. Ludzie na co dzień współpracują znacznie częściej, niż gdyby kierowali się wyłącznie racjonalną oceną własnych interesów. Gdy psychologowie proszą ochotników o rozegranie dylematu więźnia, badani czasem zachowują milczenie, mimo wysokiej nagrody za współpracę z władzą. Jeśli „Alicja” wierzy, że „Bob” zaczął sypać, sam też na pewno na niego doniesie. Jeśli jest przekonana, że „Bob” będzie milczał, prawdopodobnie i tak go wyda, choć być może zachowa milczenie. „Być może” to zazwyczaj zaledwie $20 \%$ przypadków, ale to i tak promyk nadziei w paskudnej sytuacji. Naprawdę dziwne jest jednak to, że gdy „Alicja” nie ma pewności co zrobi „Bob”, wzrasta jej skłonność do zachowania milczenia. Żadna stuprocentowo rozsądna istota nie zachowałaby się w ten sposób. Zgodnie z klasyczną logika, jeśli „Alicja” uważa, że jest 50\% szans na to, że „Bob” będzie milczał, powinna uśrednić swoje dwie skłonności i zachować milczenie w 10\% przypadków. Jednak w badaniach psychologicznych, ochotnicy w podobnych sytuacjach zachowują milczenie w 40\% przypadków, co obrazują tabele nr 1-3 (Musser, 2012: 57-61).

W 2009 r. psychologowie: E. Pothos (City University London) i J. Busemeyer (Indiana University Bloomington) opracowali model kwantowy, który odtwarza wyniki powyższych badań. Ów model działa, gdyż ludzie nie mają ustalonych preferencji. Jak 
mówi J. Busemeyer: „Jesteśmy uzależnieni od kontekstu. Nie ma czegoś takiego jak nasze postawy, które siedzą grzecznie i czekają na pomiar”. Superpozycje stanów kwantowych odzwierciedlają zjawisko mieszanych uczuć. Nie oznacza to jednak, że nasz mózgi są, dosłownie biorąc, komputerami kwantowymi, jak spekulują niektórzy fizycy. Jest raczej tak, że fizyka kwantowa jest użyteczną metaforą płynności ludzkich uczuć (ibidem).

Tabela 1

\section{Dylemat więźnia - sytuacja początkowa}

\begin{tabular}{|l|l||}
\hline $\begin{array}{l}\text { Policja zatrzymuje i przestuchuje Alicję i Boba pod zarzutem kradzieży. Jeśli oboje będą trzymać język za zęba- } \\
\text { mi, oboje wyjdą na wolność, jeśli tylko jedno z nich zadenuncjuje drugie, wyjdzie na wolność z nagrodą, a drugie } \\
\text { wyląduje w więzieniu; jeśli oboje będę donosić, oboje trafią za kratki. }\end{array}$ \\
\hline \multicolumn{3}{|c||}{ Alicja } \\
\hline Milczeć czy donosić?
\end{tabular}

Źródło: G. Musser, Nowe oświecenie. Fizyka kwantowa. Teoria kwantowa wydawała się gwoździem do trumny zdrowego rozsqdku. Teraz jawi się jego ratunkiem, „Świat Nauki” 2012, nr 12, s. 57-61.

\section{Dylemat więźnia - racjonalny i nieracjonalny tok myślenia}

\begin{tabular}{|c|c|}
\hline \multicolumn{2}{|c|}{ Racjonalny tok myślenia } \\
\hline \multicolumn{2}{|c|}{$\begin{array}{l}\text { Alicja ocenia, co Bob najprawdopodobniej zrobi. Stwierdza, że bez względu na wybór Boba sama odniesie naj } \\
\text { więcej korzyści, idąc na współpracę. Bob rozumuje analogicznie. } \\
\text { Wyniki: oboje będą donosić i oboje zostaną ukarani. } \\
\text { Jeśli myśleć racjonalnie, nie ma sposobu na uniknięcie wyroku }\end{array}$} \\
\hline \multicolumn{2}{|c|}{ Alicja } \\
\hline \multicolumn{2}{|c|}{ Alicja ocenia, co jej zdaniem zrobi Bob. } \\
\hline \multicolumn{2}{|l|}{ Alicja decyduje co zrobić - donosić. } \\
\hline \multicolumn{2}{|c|}{$\begin{array}{c}\text { Skłonność racjonalna } \\
\text { Dbać o siebie na podstawie oceny sytuacji: }\end{array}$} \\
\hline Ocena sytuacji & Wybór \\
\hline Bob będzie milczeć & „Współpraca” ze śledczym \\
\hline Bob będzie donosić & „Współpraca” ze śledczym \\
\hline
\end{tabular}




\begin{tabular}{|c|c|}
\hline \multicolumn{2}{|c|}{ Nieracjonalny tok myślenia } \\
\hline \multicolumn{2}{|c|}{$\begin{array}{l}\text { Myśląc życzeniowo, Alicja wyobrażała sobie, że jeśli będzie milczeć, Bob z pewnością zrobi to samo. } \\
\text { To oznacza, że wyobraża sobie wybór Boba, kierując się własnym zamiarem. Ten nieuzasadniony optymizm } \\
\text { otwiera drogę do korzystnego dla obojga rozwiązania sytuacji. }\end{array}$} \\
\hline \multicolumn{2}{|c|}{ Alicja } \\
\hline \multicolumn{2}{|l|}{ Alicja decyduje, co zrobi. } \\
\hline \multicolumn{2}{|c|}{ Następnie ocenia, co jej zdaniem zrobi Bob. } \\
\hline \multicolumn{2}{|l|}{ Alicja milczy } \\
\hline \multicolumn{2}{|c|}{$\begin{array}{c}\text { Skłonność nieracjonalna } \\
\text { Zmienić ocenę sytuacji w zależności od swojego zamiaru: }\end{array}$} \\
\hline Zamiar & Ocena sytuacji \\
\hline Milczenie & Bob będzie milczeć \\
\hline Denuncjacja & Bob będzie donosić \\
\hline
\end{tabular}

Źródlo: G. Musser, Nowe oświecenie. Fizyka kwantowa. Teoria kwantowa wydawała się gwoździem do trumny zdrowego rozsadku. Teraz jawi sie jego ratunkiem, „Świat Nauki” 2012, nr 12, s. 57-61.

Dylemat więźnia - rozumowanie kwantowe

\section{Rozumowanie kwantowe}

Racjonalne i nieracjonalne skłonności konkurują ze sobą.

Śledczy mogą manipulować sytuacją poprzez sugerowanie podejrzanemu, co zrobi druga osoba.

Jeśli śledczy nic nie mówi, z logicznego punktu widzenia, podejrzany nie powinien zmieniać strategii.

Jednak, gdy psychologowie proszą badanych o odegranie roli podejrzanych, niepewność zwykle zmniejsza prawdopodobieństwo współpracy ze śledczym.

Tłumaczy to model kwantowy, w którym prawdopodobieństwa różnych wyborów łączą się inaczej, niż podpowiada intuicja.

\begin{tabular}{||l|l||}
\hline \multicolumn{1}{|c|}{ Co powie śledczy? } & \multicolumn{1}{c|}{ Co zrobi Alicja? } \\
\hline Bob doniesie & Alicja doniesie w 100\% przypadków \\
\hline Bob będzie milczał & Alicja doniesie w 80\% przypadków \\
\hline Nic & $\begin{array}{l}\text { Logika klasyczna: } \\
\text { Alicja doniesie w 90\% przypadków (średnia z 80\% } \\
\text { i 100\%) }\end{array}$ \\
\hline $\begin{array}{l}\text { Logika kwantowa: } \\
\text { Alicja doniesie w 60\% przypadków (różne motywacje, } \\
\text { by donosić, raczej się niwelujac, zamiast sumować, co } \\
\text { można zaobserwować w modelu kwantowym) }\end{array}$ \\
\hline
\end{tabular}

Źródło: G. Musser, Nowe oświecenie. Fizyka kwantowa. Teoria kwantowa wydawała się gwoździem do trumny zdrowego rozsqdku. Teraz jawi się jego ratunkiem, „Świat Nauki” 2012, nr 12, s. 57-61.

Czy symulacje, szybkie komputery, skomplikowane matematyczne obliczenia danych z przeszłości i teraźniejszości rzeczywiście pokazują nam co będzie w przyszłości? Nie, ale to nie jest argument, by zaprzestać prób. Czasami jednak wypada mieć więcej pokory wobec świata. 
Jak zauważa D. H. Freedman, załamanie rynku w 2008 r., wskutek którego światowa gospodarka wpadła recesję, miało wiele przyczyn. Jedną z nich była matematyka (także w mniej dosłownym sensie). Firmy inwestycyjne opracowały na tyle zawiłe sposoby obrotu pieniędzmi swoich klientów, że niepostrzeżenie uzależniły się od trudnych do zrozumienia przez zwykłych śmiertelników „,magicznych” wzorów na ocenę podejmowanego ryzyka. Jednak w 2008 r. boleśnie przekonaliśmy się, że te formuły matematyczne - modele - bywają wyjątkowo zwodnicze (Freedman, 2011: 59-61). Środowisko rynków finansowych nie jest jedynym, w którym ważne decyzje podejmuje się często na podstawie wyników uzyskanych dzięki modelom matematycznym. Kłopoty pojawiają się zwykle podczas opisywania zjawisk szczególnie złożonych lub na których temat informacje są trudno dostępne. W przypadku modeli finansowych mamy do czynienia i z jednym, i z drugim. Tymczasem finansiści wydają się niemal bezkrytycznie ufać teoriom naukowym, nawet tym zbudowanym na wyjątkowo kruchych podstawach (ibidem).

Oczywiście przyczyn załamania gospodarczego było wiele i obwinianie o katastrofę jedynie wadliwych modeli ryzyka to nadmierne uproszczenie. Do kryzysu doprowadziły także błędy ludzkie, sytuacja polityczna i obowiązujące przepisy. Jednak modele ryzyka były bez wątpienia istotnym elementem wspólnym lub nawet warunkiem sine qua non zapoczątkowania katastrofy. Upadek modeli oceny ryzyka, jaki mieliśmy okazję obserwować w latach 2007 i 2008, można właściwie łatwo wytłumaczyć. W założeniu miały one symulować złożone oddziaływania pomiędzy różnymi procesami rynkowymi i na bieżąco uwzględniać wszelkie wahania podaży i popytu - zmiany stóp procentowych i cen akcji, obligacji, opcji na zakup akcji oraz innych instrumentów finansowych. Nawet gdyby taka symulacja dobrze odzwierciedlała rzeczywistość - a to bardzo wątpliwe - nie udało się za jej pomocą przewidzieć jednej, istotnej sytuacji. Mianowicie: co by się stało, gdyby wszyscy jednocześnie zechcieli pozbyć się swoich zasobów? Ten czarny scenariusz zrealizował się we wrześniu 2008 r., kiedy rząd federalny USA zadecydował, że nie przyjdzie z pomocą upadającemu bankowi Lehman Brothers, co spowodowało, że ten $\mathrm{z}$ dnia na dzień stał się niewypłacalny. Lawina kolejnych bankructw została w końcu zatrzymana dzięki ogromnym sumom wyasygnowanym przez rząd federalny (Freedman, 2011: 59-61).

Tymczasem w 2007 r. modele wskazywały, że ryzyko niewypłacalności jakiejkolwiek znaczącej instytucji finansowej jest znikome. M. Avellaneda, matematyk z New York University specjalizujący się w modelach ryzyka finansowego, twierdzi, że największą ich wadą było pominięcie bardzo istotnej zmiennej - płynności, czyli zdolności rynku do niepowodującej straty zmiany formy aktywów. To kluczowy element. Równie dobrze można było opracować wzór przewidujący ryzyko spóźnienia przylotu samolotu z pominięciem zmiennej związanej z warunkami atmosferycznymi. Kiedy w 2008 r. ceny nieruchomości zaczęły spadać, mało kto wiedział, ile te instrumenty są warte, wskutek czego straciły one płynność, a obrót nimi zamarł. W tej sytuacji banki mające je w swoich portfelach straciły możliwość ich spieniężenia, doprowadzając do wybuchu paniki (ibidem).

D. H. Freedman konkluduje, że pominięcie kluczowej zmiennej wydaje się być szaleństwem, ale naukowcy robią to nader często. Zdarza się, że badacze nie zdają sobie sprawy, iż dana zmienna ma kluczowe znaczenie, bądź po prostu nie są w stanie dokładnie określić praw nią rządzących (ibidem). 
Psycholog, prof. W. Łukaszewski odnośnie prognozowania przywołuje pewne zdarzenia sprzed ponad półwiecza. W roku 1950, w znakomitym czasopiśmie „Problemy” publikowano prognozy na rok 2000. O tym, jak będzie wyglądał świat za 50 lat wypowiadały się najznamienitsze polskie umysły - wybitni uczeni, specjaliści, publicyści. W roku 2000 materiały te można było w najlepszym razie traktować jak teksty humorystyczne. Prognozy pozbawione były wyobraźni, nazbyt zakotwiczone były w rzeczywistości polskiej, nieokrzepłej jeszcze po straszliwej wojnie. Ciążyła na nich przeszłość. Słynący z wielu trafnych przewidywań i hipotez Stanisław Lem, choć marzył o upadku komunizmu (w roku 1982 było to - jak powiedział w rozmowie ze S. Beresiem - jego jedyne marzenie), upadku systemu komunistycznego nie przewidział. Zatem nawet nieprzeciętne kompetencje, a takie bez wątpienia miał S. Lem, nie zapewniają trafności prognozowania (Łukaszewski, 2009: 24-28).

Zjawiska prognozowania są dość zróżnicowane. Z jednej strony to terytorium wróżbitów. Tu mieszczą się prorocy, wieszczowie i ich wieszczenia. Tu znajdą swoje miejsce wielbiciele gier liczbowych i ich typowania. Z drugiej strony, tu spotkamy uczonych formułujących swoje hipotezy. Tu wreszcie znajdą się specjaliści od przewidywania zdarzeń i trendów oraz ich prognozy. Wrzucenie tego wszystkiego do ,jednego worka" wydaje się krokiem dość nonszalanckim, ale usprawiedliwionym, bo są to różne odmiany tego samego zjawiska. Ta różnorodność zjawisk pokazuje, na ile sposobów usiłujemy radzić sobie z niepewnością przyszłości i jak bardzo pragniemy posiąść zdolność przewidywania zdarzeń. Wprawdzie niepewność jest silnym bodźcem skłaniającym nas do myślenia, ale przedłużającą się niepewność jest źródłem poczucia braku kontroli nad zdarzeniami, a nawet leku (ibidem). To z kolei napędza koniunkturę różnego rodzaju osobom, instytucjom oraz przedsięwzięciom mającym przewidywać przyszłość (Zawód, 2012: 70-73; Marczuk).

By tego lęku było jak najmniej trzeba zatem - chociażby za pomocą symulacji - ćwiczyć przewidywanie przyszłości. Jednak, choć to uwaga bardziej filozoficzna niż politologiczna, ćwiczyć na modelach, ale żyć w realnym świecie.

\section{Bibliografia}

Bellhouse D. (2007), The Problem of Waldegrave, „Electronic Journ@1 for History of Probality and Statistics", Vol. 3, No. 2, http://www.emis.de/journals/JEHPS/Decembre2007/Bellhouse.pdf (31.07.2013).

Berlinger G., Modeling \& Simulation, http://www.systems-thinking.org/modsim/modsim.htm (31.07.2013).

Boryń P., Obłoza W., S.E.N.S.E., http://www.csikgw.aon.edu.pl/index.php/pl/modelowanie/102-sense.html (31.07.2013).

Centrum Symulacji i Komputerowych Gier Wojennych (CSiKGW) - O nas, http://csikgw.aon.edu.pl/ (31.07.2013).

Donaj Ł. (2013), Chosen Problems of Forecasting Social Phenomena, „Reality of Politics. Estimates - Comments - Forecasts", No. 3.

Dylemat więźnia, http://www.nbportal.p1/pl/commonPages/EconomicsEntryDetails?entryId=265\&pageId=608 (31.07.2013). 
EVE Online, http://www.gry-online.pl/S016.asp?ID=725 (31.07.2013).

Freedman D. H. (2011), Wzór na katastrofę. Ekonomia, „Świat Nauki”, nr 12.

Głowacka K., To droga ku komputerom kwantowym. Jeśli powstana, spowoduja spustoszenie (Nobel z fizyki), http://wiadomosci.gazeta.pl/wiadomosci/1,114885,12637680,_To_droga_ku_komputerom_kwantowym_Jesli_powstana_html (31.07.2013).

Guzik B., Appenzeller D., Jurek W. (2004), Prognozowanie i symulacje. Wybrane zagadnienia, Poznań.

Hykšová M., Several milestones in the history of game theory, http://euler.fd.cvut.cz/ hyksova/hyksova_milestones.pdf (31.07.2013).

Inflacja - defraudacja - palpitacja. Bank centralny dla każdego. Gdybyśmy wszyscy w porę zagrali w ,EVE Online”, żaden bankier by nam nie podskoczyt, na podst. Courrier International - „Forum” 11-17.02.2013.

Kaplan M., Kaplan E. (2008), Zawsze masz szansę...O roli przypadków w życiu, Warszawa.

Kardasz M. (2011), Model ONZ, Szkoła Dyplomacji w II Liceum Marii Skłodowskiej-Curie w Gorzowie Wielkopolskim, http://2lo.gorzow.pl/2011/11/18/polmun/ (31.07.2013).

Karwat M. (2009), Syndromatyczny charakter przedmiotu nauki o polityce, w: Demokratyczna Polska w globalizujacym się świecie - I Ogólnopolski Kongres Politologii, Warszawa 22-24.09.2009, (red.) K. A. Wojtaszczyk, A. Mirska, Warszawa.

Kubity zamiast bitów (2012), „Świat Nauki”, nr 12.

Kucharczyk M., Bitwa na tysiqce statków, straty na dziesiqutki tysięcy dolarów. Wszystko przez pomyłke, http://www.tvn24.pl/internet-hi-tech-media,40/bitwa-na-tysiace-statkow-straty-na-dziesiatki-tysiecy-dolarow-wszystko-przez-pomylke,303276.html (31.07.2013).

Lamentowicz W. (2012), Granice strategii państwa. Efekt Tsunami, Częstochowa.

Łukaszewski W. (2009), Pewna jest jedynie niepewność, „Charaktery”, nr 12.

Malinowski G., Czarny Łabędź, http://www.felieton.pl/2986_czarny-labedz.html (31.07.2013).

Marczuk J., Bruce Bueno de Mesquita i inni potentaci na rynku prognozowania przyszłości świata, http://konflikty.wp.pl/kat,106090,page,2,title,Bruce-Bueno-de-Mesquita-i-inni-potentaci-na-rynku-prognozowania-przyszlosci-swiata,wid,15760830,wiadomosc.html (31.07.2013).

Materials about forecasting made available by M. Solak (w posiadaniu autora).

McTague's J., Looking at Greenspan's Long-Lost Thesis, http://online.barrons.com/public/article/SB120917419049046805.html?mod=mktw\#articleTabs_article\%3D1 (31.07.2013).

Modelowanie i symulacja architektury systemu obrony przed broniq masowego rażenia (MaSC), wpisany przez: Redaktor serwisu, http://www.aon.edu.pl/pl/centrum-szkolenia-opbmr/3036 --modelowanie-i-symulacja-architektury-systemu-obrony-przed-broni-masowego-raenia-masc (31.07.2013).

Modelowanie matematyczne $i$ symulacje komputerowe $w$ naukach społecznych (2007), (red.) K. Winkowska-Nowak, A. Nowak, A. Rychwalska, Warszawa.

Musser G. (2012), Nowe oświecenie. Fizyka kwantowa. Teoria kwantowa wydawała się gwoździem do trumny zdrowego rozsqdku. Teraz jawi się jego ratunkiem, „Świat Nauki”, nr 2.

Nowak A. (2007) Wstęp. Modelowanie matematyczne i symulacje komputerowe w naukach spotecznych, w: Modelowanie matematyczne i symulacje komputerowe w naukach spolecznych, (red.) K. Winkowska-Nowak, A. Nowak, A. Rychwalska, Warszawa.

Poradnik pirata (bardzo poczqtkujacy), http://eve-online.com.pl/ (31.07.2013).

Prognozowanie i symulacja (2002), (red.) W. Milo, Łódź.

SENSE: Strategic Economic Needs and Security Exercise, Warsaw, 29 September-7 October 2006. Organized by: The Centre for East European Studies Warsaw University in cooperation with: 
The Ministry of Foreign Affaitrs and The Ministry of National Defence (broszura w posiadaniu autora).

SENSE: Strategic Economic Needs and Security Exercise. Fact sheets, http://www.usip.org/sites/default/files/SENSE\%20Fact\%20Sheet\%206-18-12.pdf (31.07.2013).

StetiMUN2013, http://stetimun.lo2.szczecin.pl/ (31.07.2013).

Straffin P. D. (2004), Teoria gier, Warszawa.

Stryjski K. J. (2003), Prognozy i symulacje międzynarodowe, „Studia Międzynarodowe. Zeszyty Naukowe WSSM w Łodzi”, nr 1.

Stryjski K. J. (2004), Prognozowanie i symulacje międzynarodowe, Łódź.

Sułek M. (2010), Prognozowanie i symulacje międzynarodowe, Warszawa.

Taleb N. N. (2009), Ten principles for a Black Swan-proof world, „Financial Times”, 7.04.2009.

Taleb N. N. (2007), The Black Swan: The Impact of the Highly Improbable, „The New York Times”, 22.04.2007.

Warsaw Model United Nations, http://wawmun.pl/ (31.07.2013).

Wieleba R., Symulacja, http://csikgw.aon.edu.pl/index.php/pl/symulacja/87-symulacja.html (31.07.2013).

Wróblewski M. (2009), Gra jako model spoleczny. O potrzebie grania w spoleczeństwie ponowoczesnym, „Homo Ludens”, nr 1.

Zawód jasnowidz. Innowacje (2012), rozmowa z B. D. Johnsonem, przeprowadzona przez: L. Greenemeiera, „Świat Nauki”, nr 6.

\title{
STRESZCZENIE
}

Treścią publikacji jest przedstawienie wybranych problemów prognozowania w naukach społecznych. W artykule skoncentrowano się na metodzie gier decyzyjnych/symulacyjnych, które - zwłaszcza wraz z rozwojem teorii gier oraz komputerów - są coraz częściej wykorzystywane w wielu dziedzinach. Na wybranych przykładach gier decyzyjnych/symulacyjnych - Poznań International Model United Nations 2013/POZiMUN; S.E.N.S.E. a także gry sieciowej EVE Online - wskazano jak ważne są takie ćwiczenia, by móc precyzyjniej przewidywać przyszłość. Zwrócono także szczególną uwagę na kwestię przypadku oraz czynników zakłócających, które mogą destabilizować proces przewidywania. Poruszono ponadto problem podejmowania decyzji w aspekcie klasycznej oraz kwantowej logiki.

\section{THE USE OF DECISION-MAKING/SIMULATION GAMES IN SOCIAL SCIENCES. SELECTED PROBLEMS}

\begin{abstract}
The aim of the publication is to present selected forecasting problems in social sciences. The article focused on the method of decision-making/simulation games that, especially with the development of game theory and computers, have increasingly been used in many fields. Using examples of decision/simulation games - Poznań International Model United Nations 2013/POZiMUN; S.E.N.S.E - and the online game EVE Online, the author recognised the importance of such exercises in an accurate prediction of the future. He drew special attention to the element of chance and confounding factors that may destabilise the process of prediction. $\mathrm{He}$ also raised the problem of decision-making in the context of classical and quantum logic.
\end{abstract}


